\title{
Analisis Alih Kode dan Campur Kode dalam Pembelajaran Bahasa Indonesia di SMP Negeri 3 Darul Hikmah Aceh Jaya
}

\author{
Mardhiah \\ Magister Pendidikan Bahasa dan Sastra Indonesia \\ Universitas Syiah Kuala, Indonesia \\ Email: mardhiah5386@gmail.com
}

\begin{tabular}{l}
\hline Tersedia Online di \\
\hline http://www.jurnal.unublitar.ac.id/ \\
index.php/briliant
\end{tabular}

Sejarah Artikel

Diterima pada 15 Januari 2020

Disetujui pada 4 Februari 2020

Dipublikasikan pada 29 Februari

2020 Hal. 83-97

\begin{tabular}{l}
\hline Kata Kunci \\
\hline $\begin{array}{l}\text { Alih Kode; Campur Kode; Proses } \\
\text { pembelajaran; Bahasa Indonesia }\end{array}$ \\
\hline
\end{tabular}

\section{DOI:}

http://dx.doi.org/10.28926/briliant

.v3i4.432

\begin{abstract}
Abstrak: Penelitian ini bertujuan untuk mendeskripsikan bentuk alih kode dan campur kode dalam pembelajaran Bahasa Indonesia di SMP Negeri 3 Darul Hikmah, Aceh Jaya. Metode penelitian yang digunakan adalah metode kualitatif. Data dalam penelitian ini diperoleh dari observasi yang berupa tuturan guru dan siswa. Hasil penelitian adalah bentuk alih kode dalam pembelajaran Bahasa Indonesia di SMP Negeri 3 Darul Hikmah berupa alih bahasa dan alih ragam. Alih bahasa berupa alih kode dari Bahasa Indonesia ke Bahasa Aceh, alih kode terjadi dari Bahasa Aceh ke Bahasa Indonesia, sedangkan alih ragam dari ragam formal ke ragam tidak formal dan sebaliknya. Adapun campur kode yang terjadi berupa penyisipan kata, penyisipan frasa, baster (hybrid), dan penyisipan klausa.
\end{abstract}

\section{PENDAHULUAN}

Keberagaman suku di Indonesia mengakibatkan munculnya variasi bahasa yang menjadi salah satu faktor munculnya pemilihan bahasa. Di dunia pendidikan, untuk memudahkan pencapaian tujuan pembelajaran, guru dan peserta didik akan menggunakan pemilihan bahasa yang dikuasainya. Lingkungan pendidikan sebagai lingkungan formal menuntut guru dan peserta didik berbahasa resmi, yaitu bahasa Indonesia. Apalagi pada mata pelajaran bahasa Indonesia. Proses pembelajaran dituntut menggunakan bahasa Indonesia yang baik dan benar. Hal ini seperti tercantum dalam Undang-Undang Republik Indonesia Nomor 24 tahun 2009 Pasal 27 bahwa bahasa Indonesia adalah bahasa resmi negara dan bahasa persatuan. Sebagai bahasa resmi negara, bahasa Indonesia berfungsi sebagai bahasa resmi kenegaraan, pengantar pendidikan, komunikasi tingkat nasional, pengembangan kebudayaan nasional, transaksi dan komunikasi niaga, serta sarana pengembangan dan pemanfaatan ilmu pengetahuan, teknologi, seni, dan bahasa media massa. Sebagai bahasa persatuan, bahasa Indonesia berfungsi sebagai jati diri bangsa, kebanggaan nasional, sarana pemersatu berbagai suku dan bangsa, serta sarana komunikasi antardaerah dan antarbudaya daerah.

Dalam konteks pendidikan, bahasa yang dominan digunakan di lingkungan sekolah sangat mempengaruhi kegiatan pembelajaran. Apabila seorang guru lebih sering menggunakan bahasa ibu (bahasa daerah) dalam kesehariannya saat 
berinteraksi dengan sesama guru atau peserta didik, besar kemungkinan akan adanya pemilihan bahasa, yaitu alih kode dan campur kode bahasa daerah ke dalam bahasa Indonesia atau alih kode dan campur kode bahasa Indonesia ke dalam bahasa daerah. Nababan (1991: 68) menegaskan bahwa alat utama dalam interaksi belajar mengajar antara murid dan guru adalah bahan pelajaran dan bahasa. Materi pelajaran akan mudah disampaikan apabila guru sadar akan kaidah penggunaan bahasa dalam interaksi pembelajaran. Penggunaan kaidah berbahasa yang baik dan benar digunakan dan dengan begitu dapat meningkatkan efisiensi dan efektivitas pembelajaran.

Di Aceh, penggunaan dua bahasa atau lebih dalam berkomunikasi merupakan fenomena yang biasa terjadi. Hal ini disebabkan karena orang-orang yang terlibat dalam tindak komunikasi menguasai lebih dari satu bahasa. Bahkan hingga saat ini sekurang-kurangnya terdapat 9 bahasa yang eksis di Aceh, baik itu bahasa daerah, bahasa Indonesia, maupun bahasa asing (lihat, Widarsini \& Suaida, 2016:1916). Namun, berbeda halnya di lingkungan sekolah, terutama dalam pembelajaran bahasa Indonesia, guru berusaha menggiring peserta didik untuk mampu berbahasa Indonesia yang baik dan benar dengan menghindari penggunaan bahasa daerah. Akan tetapi, terkadang ada materi yang membuat guru harus menggunakan bahasa daerah agar peserta didik memahami maksud yang ingin disampaikan oleh guru dalam pembelajaran. Bahkan, peserta didik sering bertanya dalam bahasa daerah karena merasa kurang percaya diri untuk berbahasa Indonesia. Hal ini menyebabkan terjadinya alih kode dan campur kode pada tuturan guru baik karena faktor kesengajaan atau spontanitas. Terkait hal tersebut, Sugono (2002: 21) menyatakan bahwa kriteria penggunaan bahasa yang baik adalah ketepatan memilih ragam bahasa yang sesuai dengan kebutuhan komunikasi. Pemilihan bahasa berkaitan dengan topik yang dibicarakan, tujuan pembicaraan, orang yang diajak berbicara, dan tempat pembicaraan. Dengan demikian, penggunaan bahasa dalam situasi resmi tidak harus baku karena topik pembicaraan juga menentukan pilihan penggunaan bahasa.

Lebih lanjut, Ohoiwutun (2007: 126) menyatakan bahwa dalam pembelajaran apa saja termasuk pembelajaran bahasa selalu terdapat kemungkinan terjadinya perubahan-perubahan variasi ragam bahasa. Hal ini berarti dalam proses pembelajaran ada kalanya guru menggunakan lebih dari satu bahasa dan tergantung dari situasi atau tuntutan saat kegiatan pembelajaran berlangsung. Saat peserta didik tidak memahami apa yang disampaikan oleh guru, maka guru harus memilih kode (bahasa) yang dipahami oleh peserta didik. Kode dalam konteks ini menurut Suwito (dalam Rahardi, 2001: 22) adalah satu varian di dalam hierarki kebahasaan yang dipakai dalam komunikasi. Kode tersebut merupakan istilah netral yang dapat mengacu kepada bahasa, dialek, sosiolek, atau ragam bahasa (Sumarsono, 2011:201). Jika si A mempunyai B1 bahasa Bali dan B2 bahasa Indonesia serta menguasai juga bahasa Inggris, dia dapat beralih kode dengan tiga bahasa itu. Akibat dari penggunaan dua bahasa atau lebih secara linguistik terjadi alih kode dan campur kode. Secara sederhana dapat dinyatakan bahwa penggunaan suatu bahasa tertentu kemudian beralih menggunakan bahasa lain disebut peristiwa alih kode. Sedangkan campur kode adalah peristiwa ketika guru menyelipkan unsur-unsur bahasa lain ke dalam bahasa yang digunakan. Unsur-unsur yang diselipkan tersebut tidak memiliki fungsinya sendiri. 
Terkait hal tersebut, beberapa penelitian terkait alih kode dan campur kode dalam proses pembelajaran memberikan kesimpulan yang bervariasi. Salah satunya hasil penelitian Susmita (2015) yang menyatakan bahwa guru perlu membatasi penggunaan alih kode dan campur kode dalam pengajaran bahasa di kelas. Kemudian penelitian Rulyandi, dkk. (2014) yang menyatakan bahwa penggunaan Alih kode dan campur kode berdampak positif dan negatif dalam pembelajaran bahasa Indonesia di kelas X. Penelitian lain yang berkaitan dengan alih kode juga pernah dilakukan oleh Indrayani (2017) yang bertujuan untuk mengevaluasi faktor penyebab terjadinya alih kode. Hasil penelitiannya menyatakan bahwa yaitu penggunaan alih kode dalam proses pembelajaran dilakukan karena hal tersebut dianggap prestise atau bergengsi, untuk mengimbangi kemampuan berbahasa peserta didik, dan menjaga emosi guru. Hal berbeda disimpulkan oleh Sultan (2014) dalam penelitiannya yang menyatakan bahwa penggunaan alih kode dan campur kode dalam pembelajaran bahasa Indonesia berpengaruh terhadap peningkatan keterampilan berbicara peserta didik. Artinya, penggunaan alih kode dan campur kode dalam pembelajaran bahasa Indonesia lebih baik dibandingkan dengan tanpa menggunakan alih kode dan campur kode.

Secara garis besar, hasil-hasil penelitian tersebut mengungkapkan tentang bentuk penggunaan alih kode dan campur kode dalam proses pembelajaran serta dampaknya terhadap kemampuan berbahasa siswa/siswi yang ada di sekolah. Bukan pada maksud penggunaan dalam proses pembelajarannya. Oleh karena itu, secara khusus artikel ini ingin mengkaji tentang bentuk alih kode dan campur kode yang terjadi dalam pembelajaran bahasa Indonesia yang terjadi di Aceh, tepatnya di SMP Negeri 3 Darul Hikmah. Kemudian penulis ingin memaparkan lebih rinci tentang bentuk alih kode dan bentuk campur kode serta menguraikan maksud penggunaannya dalam proses pembelajaran bahasa Indonesia di sekolah tersebut. Hal ini menjadi penting karena sebagian besar sekolah di Aceh masih menggunakan bahasa daerah dalam proses pembelajaran, dan berdasarkan observasi penulis, banyak siswa yang masih susah memahami bahasa Indonesia dengan baik sehingga tidak berani menggunakannya, termasuk dalam pelajaran bahasa Indonesia.

\section{METODE}

Penelitian ini menggunakan metode kualitatif dengan pendekatan deskriptif, yaitu penelitian yang dilakukan untuk menggambarkan dengan detail dan ilmiah tentang masalah yang diteliti. Menurut Chaer (dalam Nazir, 2005: 54) jenis penelitian deskriptif sangat cocok untuk memahami struktur bunyi (fonologi) struktur kata (morfologi) struktur kalimat (sintaksis). Lebih lanjut Arikunto (2006: 194) menyatakan bahwa penelitian deskriptif tidak dimaksudkan untuk menguji hipotesis tertentu, tetapi hanya menggambarkan apa adanya tentang suatu gejala atau keadaan.

Penelitian ini dilaksanakan di SMP Negeri 3 Darul Hikmah yang beralamat di Desa Gunong Cut, Kecamatan Darul Hikmah Kabupaten Aceh Jaya. Pemilihan lokasi ini didasarkan pada tiga pertimbangan, Pertama, SMP Negeri 3 Darul Hikmah adalah SMP terjauh yang berjarak 12 kilometer dari jalan raya bila dibandingkan dengan SMP lainnya di Kecamatan Darul Hikmah. Kedua, Peserta didik dan guru di SMP Negeri 3 Darul Hikmah berlatar belakang suku Aceh yang 
terbiasa menggunakan bahasa Aceh dalam berinteraksi di luar lingkungan sekolah. Ketiga, peristiwa alih kode dan campur kode masih banyak ditemukan dalam kegiatan pembelajaran bahasa Indonesia di SMP Negeri 3 Darul Hikmah. Proses pengumpulan data mulai dilakukan pada tanggal 2 Februari sampai 16 Mei 2019, bertepatan dengan tahun ajaran 2018/2019 semester genap. Data yang dikumpulkan berupa tuturan guru yang didokumentasikan pada saat jadwal pembelajaran bahasa Indonesia berlangsung di setiap kelas.

Adapun teknik pengumpulan data yang penulis gunakan dalam penelitian ini adalah teknik observasi partisipasi pasif. Peneliti melakukan pengamatan dengan cermat di lokasi penelitian tetapi tidak ikut terlibat dalam kegiatan pembelajaran. Teknik observasi diterapkan dengan cara menyimak segala kegiatan komunikasi yang dilakukan oleh guru dan peserta didik di kelas VII, VIII, dan IX SMP Negeri 3 Darul Hikmah tanpa adanya keterlibatan peneliti secara langsung dalam kegiatan komunikasi tersebut. Penulis menggunakan teknik ini dengan dasar pemikiran bahwa perilaku berbahasa hanya dapat benar-benar dipahami jika peristiwa berbahasa itu berlangsung dalam situasi yang sebenarnya yang berada dalam konteks yang lengkap (Mahsun, 2007: 218-219). Setelah data terkumpul, penulis melakukan analisis data model Miles dan Huberman.

\section{HASIL}

Penggunaan bahasa pada peristiwa tutur (pembelajaran) di dalam kelas tidak terlepas dari kebiasaan komunikasi di luar kelas, saat pembelajaran belum dimulai atau sudah selesai. Peneliti menemukan bahwa kode bahasa yang digunakan guru dalam pembelajaran terdiri atas dua kode. Kode-kode tersebut berupa bahasa Indonesia yang selanjutnya disingkat menjadi BI dan kode bahasa Aceh yang selanjutnya disingkat menjadi BA. Kode BI dan kode BA lebih sering digunakan dalam tuturan guru dan peserta didik saat pembelajaran. Kedua kode tersebut muncul akibat adanya peristiwa kontak bahasa antara guru dan peserta didik saat memberi dan menerima informasi.

Berikut ini akan diuraikan hasil penelitian mengenai alih kode dan campur kode yang ditemukan dari tuturan guru dan peserta didik dalam pembelajaran bahasa Indonesia di kelas VII, kelas VIII, dan kelas IX SMP Negeri 3 Darul Hikmah.

\section{Bentuk Alih Kode}

Alih kode yang terdapat dalam tuturan guru bahasa Indonesia di SMP Negeri 3 Darul Hikmah berupa alih bahasa dan alih ragam. Alih bahasa meliputi (1) alih kode dari BI ke BA, dan (2) alih kode dari BA ke BI. Alih Ragam meliputi (1) alih kode dari ragam resmi ke ragam tidak resmi, dan (2) alih kode dari ragam tidak resmi ke ragam resmi.

\section{a. Alih Kode BI ke BA}

Bahasa Indonesia adalah bahasa pengantar utama dalam pembelajaran. Walau pun guru merespons informasi yang disampaikan peserta didik dalam bahasa Aceh dengan bahasa Aceh pula, guru wajib melakukan alih kode kembali ke dalam bahasa Indonesia. Dari hasil observasi awal, penulis melihat guru SMP Negeri 3 Darul Hikmah lebih sering berkomunikasi dalam bahasa Aceh baik dengan sesama guru atau pun dengan peserta didik. Penggunaan bahasa Aceh sering juga dijumpai dalam percakapan guru dengan peserta didik saat pembelajaran dimulai dan saat pembelajaran berakhir. Adapun bentuk alih kode 
ke dalam bahasa Aceh yang terjadi dalam pembelajaran bahasa Indonesia di SMP Negeri 3 Darul Hikmah adalah sebagai berikut.

Ragam data yang penulis temukan terkait dengan alih kode dalam proses pembelajaran bahasa Indonesia secara garis besar dilakukan untuk mempermudah dalam memberikan pemahaman kepada peserta didik. Contoh penggunaan alih kode dan tujuan dari alih kode tersebut dapat dilihat dalam tabel berikut ini:

Table 1. Contoh penggunaan alih kode dan tujuan dari alih kode

\begin{tabular}{|c|c|c|}
\hline$\sqrt{0}$ & Int & \\
\hline 1 & $\begin{array}{l}\text { Guru : Baiklah anak-anak } \\
\text { sekalian, untuk mengawali } \\
\text { pembelajaran, ibu periksa } \\
\text { kehadiran dulu ya. } \\
\text { Siswa: Ya, Bu } \\
\text { Guru: Afzan } \\
\text { Siswa 1: Hadir, Buk } \\
\text { Guru: Agusvina } \\
\text { Siswa 1: Hana ijak, Buk. } \\
\text { (tidak hadir bu) } \\
\text { Guru: Pue na beurita? (apa } \\
\text { ada kabar) }\end{array}$ & $\begin{array}{l}\text { Alih kode dari BI ke BA yang terdapat dalam tuturan } \\
\text { guru seperti pada data (1) berupa kalimat tanya "Pue na } \\
\text { beurita?" yang maksudnya "Apa ada berita?" untuk } \\
\text { menunjukkan bahwa guru menanggapi informasi yang } \\
\text { disampaikan peserta didik dengan serius. Karena } \\
\text { sebelumnya informasi yang disampaikan oleh peserta } \\
\text { didik juga dalam bahasa Aceh "Hana ijak, Buk." "Dia } \\
\text { tidak hadir, Bu" Selain itu, guru juga bermaksud untuk } \\
\text { menunjukkan keakraban dan kepedulian terhadap peserta } \\
\text { didik yang tidak hadir. Dengan alih kode ke dalam bahasa } \\
\text { Aceh, biasanya informasi mengenai kepribadian yang } \\
\text { diperoleh dari peserta didik akan lebih banyak }\end{array}$ \\
\hline 2 & $\begin{array}{l}\text { Guru: Coba kalian } \\
\text { perhatikan, ini salah satunya } \\
\text { adalah Venus. Venus yang } \\
\text { kita ketahui dia berada di } \\
\text { antara apa? Di antara } \\
\text { matahari dan ... } \\
\text { Siswa 1: Bumi } \\
\text { Guru: Teuma deuh bak } \\
\text { tanyö̈ ata nyö? }\end{array}$ & $\begin{array}{l}\text { Guru melakukan alih kode berupa kalimat tanya dalam } \\
\text { bahasa Aceh "Teuma deuh bak tanyoë ata nyö?" artinya } \\
\text { "jadi, tampak pada kita benda ini?" alih kode BA ini } \\
\text { dimaksudkan guru untuk mengharapkan jawaban atau } \\
\text { informasi baru yang dimiliki oleh peserta didik untuk } \\
\text { dihubungkan dengan materi tentang teks hasil observasi } \\
\text { yang sedang dijelaskan oleh guru. Guru ingin } \\
\text { menjelaskan bahwa planet itu tidak bisa terlihat dengan } \\
\text { mata biasa, tapi membutuhkan alat khusus yang biasa } \\
\text { digunakan oleh ilmuwan. }\end{array}$ \\
\hline 3 & $\begin{array}{l}\text { beda berita } \\
\text { ita? } \\
\text { m) } \\
\text { beda beurita } \\
\text { a? }\end{array}$ & $\begin{array}{l}\text { enunjukkan adanya perilaku alih kode BA dalam } \\
\text { ntuk kalimat tanya. Kalimat tersebut berupa "pue beda } \\
\text { urita ngoen cerita?" artinya "Apa beda berita dengan } \\
\text { rita?" Alih kode ini dilakukan guru untuk menegaskan } \\
\text { rtanyaan sebelumnya yang disampaikan dalam bahasa } \\
\text { donesia. }\end{array}$ \\
\hline 4 & $\begin{array}{l}\text { Guru : Kiban hi bentuk } \\
\text { jih? Hi tikoh kon? Na hi } \\
\text { tikoh? }\end{array}$ & $\begin{array}{l}\text { Guru melakukan alih kode berbentuk bahasa Aceh } \\
\text { "Kriban hi bentuk jih? Hi tikoh kon? Na hi tikoh?" } \\
\text { Maksudnya "Bagaimana bentuknya? Mirip tikus kan? } \\
\text { Ada mirip tikus?" Alih kode tersebut terjadi dari BI ke } \\
\text { BA dimaksudkan guru untuk meminta deskripsi pada } \\
\text { peserta didik tentang ciri-ciri kelelawar. }\end{array}$ \\
\hline 5 & $\begin{array}{l}\text { Guru: Akai, tetapi tanyoe } \\
\text { na tamanfaat akai nyan? } \\
\text { Sebagian Siswa: Han } \\
\text { Sebagian Siswa: } N a \\
\text { Guru: Ladom na. pat iduk } \\
\text { akai nyan? }\end{array}$ & $\begin{array}{l}\text { Penggunaan alih kode ke dalam bahasa Aceh "Akai, } \\
\text { tetapi tanyoe na tamanfaat akai nyan?" yang maksudnya } \\
\text { "Akal, adakah kita manfaatkan akal itu?" kemudian } \\
\text { dilanjutkan "Ladom na. pat iduk akai nyan?" yang } \\
\text { maksudnya "Sebagian ada, dimana letak akal?" Alih kode } \\
\text { ke dalam bahasa Aceh tersebut dimaksudkan guru untuk } \\
\text { memberikan pemahaman nilai sikap kepada peserta didik }\end{array}$ \\
\hline
\end{tabular}

Secara umum, dari data yang ditemukan penulis, dapat dikatakan bahwa setiap guru bahasa Indonesia yang mengajar di kelas VII, kelas VIII, dan kelas IX 
SMP Negeri 3 Darul Hikmah menggunakan kode BA dalam mengajukan pertanyaan untuk mendapatkan informasi detail tentang peserta didik, untuk memancing informasi baru, dan untuk menegaskan kembali pertanyaan awal dalam kode lain.

\section{b. Alih Kode dari BA ke BI}

Bahasa Aceh merupakan bahasa ibu bagi kebanyakan guru dan peserta didik yang tinggal di Kecamatan Darul Hikmah. Sebagaimana disampaikan oleh Hanafiah (1984: 1) fungsi umum bahasa Aceh ialah sebagai alat komunikasi dalam keluarga dan masyarakat Aceh sebagai pengungkap pikiran dan kehendaknya.

Hal itu juga dilakukan oleh guru bahasa Indonesia di SMP Negeri 3 Darul Hikmah seperti pada data berikut:

Guru: "Na beurita?"

Siswa 1: "Saket, Buk. Bunoe geupegah le mak jih"

Guru: "Ya, untuk yang lain, saat tidak bisa hadir ke sekolah, Ibu harap juga memberikan informasi agar tidak dibuat alpa di absen."

Semua Siswa: "Ya, Buk."

Alih Kode BI pada data di atas yang dilakukan guru berupa kalimat "Ya, untuk yang lain, saat tidak bisa hadir ke sekolah, Ibu harap juga memberikan informasi agar tidak dibuat alpa di absen." dimaksudkan untuk menggiring kembali peserta didik menggunakan bahasa Indonesia. Ajakan tersebut terlihat direspons oleh peserta didik dengan jawaban "Ya, Buk."

Alih kode BA ke BI sering dilakukan oleh guru saat melihat peserta didik sudah banyak berkomunikasi dengan kode BA. Hal ini perlu dilakukan guru untuk mengubah kembali konteks atau suasana belajar bahwa pembelajaran bahasa Indonesia sedang berlangsung saat itu, dan sudah seharusnya guru dan peserta didik berbahasa Indonesia. Berikut ini beberapa bentuk alih kode BA ke BI yang dipraktikkan oleh guru dalam proses pembelajaran Bahasa Indonesia:

Tabel 2. bentuk alih kode BA ke BI dalam proses pembelajaran BI

\begin{tabular}{|c|l|l|}
\hline No & \multicolumn{1}{|c|}{ Interaksi/komunikasi } & \multicolumn{1}{c|}{ Analisis } \\
\hline 1 & $\begin{array}{l}\text { Guru: lage nyan keuh, mirip bak } \\
\text { jambe kaca nyan, meunyoe ta } \\
\text { tak bak jih, iteubit geutah mirah, } \\
\text { boh jih persis lage nyan. Teuma } \\
\text { meunyoe tanyoe manusia } \\
\text { hanjeut tapajoh, Cuma orang ini, } \\
\text { makhluk ini yang bisa makan. } \\
\text { Indonesia berupa kalimat "Cuma orang ini, } \\
\text { makhluk ini yang bisa makan." Alih kode ini } \\
\text { dimaksudkan guru untuk mendeskripsikan } \\
\text { kembali ke dalam bahasa Indonesia penjelasan- } \\
\text { penjelasan guru yang sebelumnya menggunakan } \\
\text { bahasa Aceh }\end{array}$ \\
\hline $\mathbf{2}$ & $\begin{array}{l}\text { Guru: Heuh, boh timon tikoh. } \\
\text { Kelihatannya sangat indah ya, } \\
\text { sangat cantik-cantik, tapi } \\
\text { memabukkan bila kita makan } \\
\text { karena itu bukan makanan kita } \\
\text { tapi makanan mereka. }\end{array}$ & $\begin{array}{l}\text { Bentuk alih kode tersebut menunjukkan } \\
\text { deskripsi pemahaman peserta didik tentang } \\
\text { timon tikoh." Maksudnya "mentimun tikus" ke } \\
\text { dalam bahasa Indonesia. }\end{array}$ \\
\hline $\mathbf{3}$ & $\begin{array}{l}\text { Guru: "Teuwo? Peu yang na } \\
\text { teuingat?" } \\
\text { Siswa: (diam) }\end{array}$ & $\begin{array}{l}\text { Menunjukkan penggunaan alih kode dari kode } \\
\text { BA berupa "Teuwo? Peu yang na teuingat?" } \\
\text { yang beralih ke kode BI berupa "Dari 50 soal, }\end{array}$ \\
\hline
\end{tabular}




\begin{tabular}{|c|c|c|}
\hline & $\begin{array}{l}\text { Guru: "Dari } 50 \text { soal, soal yang } \\
\text { mana yang kalian masih } \\
\text { mengingatnya apa yang } \\
\text { menjadikan soal tersebut susah } \\
\text { sehingga kalian ragu untuk } \\
\text { menjawab? Sebutkan pokok } \\
\text { utamanya saja, bu ini tentang ini } \\
\text { bu, biar ibu bahas sekarang. Ibu } \\
\text { rasa tentang gagasan utama dan } \\
\text { kalimat utama ini paling } \\
\text { mudah." }\end{array}$ & $\begin{array}{l}\text { soal yang mana yang kalian masih mengingatnya } \\
\text { apa yang menjadikan soal tersebut susah } \\
\text { sehingga kalian ragu untuk menjawab? Sebutkan } \\
\text { pokok utamanya saja, bu ini tentang ini bu, biar } \\
\text { ibu bahas sekarang. Ibu rasa tentang gagasan } \\
\text { utama dan kalimat utama ini paling mudah." } \\
\text { Alih kode ke dalam bahasa Indonesia tersebut } \\
\text { dimaksudkan guru untuk mengarahkan kembali } \\
\text { peserta didik menyampaikan alasan-alasan atau } \\
\text { keluhan mereka ke dalam bahasa Indonesia. } \\
\text { Kondisi ini juga menunjukkan guru melakukan } \\
\text { Alih kode BA ke BI karena ingin mengubah } \\
\text { kembali suasana hati yang sebelumnya terlihat } \\
\text { kecewa dengan jawaban peserta didik "tuwoe" } \\
\text { maksudnya "lupa" agar kembali pada suasana } \\
\text { pembelajaran yang serius. Dengan mengubah } \\
\text { bahasa ke dalam kode BI guru bisa mengatur } \\
\text { kembali konteks pembelajaran melalui kalimat- } \\
\text { kalimat dalam bahasa Indonesia. }\end{array}$ \\
\hline 4 & $\begin{array}{l}\text { Siswa 1: Buk, lôn hana kupeuget } \\
\text { laporan membaca buku. } \\
\text { Guru: Pakon hana peuget? } \\
\text { Siswa 2: Hana ibloe kertah hvs } \\
\text { jih, Buk. } \\
\text { Guru: Mengapa Farhan tidak } \\
\text { kasih tahu ibu? } \\
\text { Siswa 1: Male, Buk. } \\
\text { Guru: Farhan ke koperasi } \\
\text { sekarang, bilang sama bu Siti ibu } \\
\text { suruh ambil kertas hvs seribu. } \\
\text { Siswa 1: Iya, Buk. }\end{array}$ & $\begin{array}{l}\text { Guru melakukan alih kode dari BA ke BI. Kode } \\
\text { BA tersebut berupa kalimat "Pakon hana } \\
\text { peuget?" yang bermakna "Mengapa tidak buat?" } \\
\text { beralih ke BI berupa kalimat "Mengapa Farhan } \\
\text { tidak kasih tahu ibu?" dan dilanjutkan dengan } \\
\text { kalimat "Farhan ke koperasi sekarang, bilang } \\
\text { sama bu Siti ibu suruh ambil kertas hvs seribu." } \\
\text { Kode BA yang digunakan guru pada data (18) } \\
\text { hanya untuk merespons kode BA yang } \\
\text { digunakan oleh peserta didik. Kemudian guru } \\
\text { melakukan alih kode BI untuk membawa peserta } \\
\text { didik kembali pada konteks komunikasi bahasa } \\
\text { Indonesia. Hal ini juga untuk membiasakan } \\
\text { peserta didik berpendapat dan menjelaskan } \\
\text { sesuatu dalam bahasa Indonesia. }\end{array}$ \\
\hline
\end{tabular}

Dari data-data yang dianalisis terlihat penggunaan alih kode ke dalam bahasa Indonesia berupa kalimat untuk mendeskripsikan kembali informasiinformasi yang sebelumnya disampaikan oleh peserta didik dalam bahasa Aceh. Guru melakukan alih kode BI karena menyadari konteks pembelajaran yang seharusnya berlangsung menggunakan bahasa Indonesia yang baik dan benar. Alih kode BA hanya digunakan sebagai strategi untuk mengumpulkan informasi atau pengetahuan yang dimiliki peserta didik agar bisa dikaitkan dengan materi pembelajaran.

\section{c. Alih Kode dari Ragam Resmi ke Ragam Tidak Resmi}

Alih kode yang berupa alih ragam yang terdapat dalam tuturan guru saat pembelajaran bahasa Indonesia bisa dilihat pada data berikut:

Guru: "Ada sebuah cerita wacana teros ditanyak nantik ke bawahnya, yang di atas itu soalnya, ibu berulang kali mengatakan di atas itu disebut, kalau bahasa Indonesia itu ada wacana, kita bilang sehariharinya ada cerita, cerita teros setelah kita baca cerita kita pahami cerita tersebut, dari satu cerita itu bisa menimbulkan tiga 
pertanyaan dengan cerita yang sama atau pun dibolak-balik. Ini cuman dibolak-balik, kan ibu sudah bilang, ini punya 2018.

Data tersebut menunjukkan guru menggunakan alih kode ke ragam tidak resmi atau ragam santai dengan adanya penggunaan kata tidak baku berupa (1) teros ditanyak nantik, (2) bilang, (3) teros, (4) cuman, (5) kan ibu sudah bilang. Penggunaan alih kode ke ragam tidak resmi ini dipengaruhi oleh kebiasaan berbahasa pertama (B1) bahasa Aceh. Guru bermaksud untuk membuat suasana pembelajaran tidak terlalu kaku dan agar peserta didik berani mengungkapkan ide dan gagasannya meskipun dalam bahasa Aceh.

Berikut ini beberapa bentuk alih kode dari ragam resmi ke ragam tidak resmi dalam proses pembelajaran bahasa Indonesia di SMP Darul Hikmah:

Tabel 3. Bentuk alih kode dari ragam resmi ke ragam tidak resmi

\begin{tabular}{|c|c|c|}
\hline No & Interaksi/komunikasi & Analisis \\
\hline 1 & $\begin{array}{l}\text { Guru: Contohnya Waktu Indonesia Barat dan } \\
\text { Waktu Indonesia Timur. Itu selisih, selisih } \\
\text { jamnya, kalau kita dengan orang Arab, berapa } \\
\text { selisih kita dengan orang Arab? hampir } \\
\text { delapan jam kalau enggak salah ibu. Kalau } \\
\text { Malaysia itu kita satu jam selisih dengan orang } \\
\text { Malaysia. Kalau kita dengan Jakarta itu selisih } \\
\text { juga, jam enam mereka itu sudah Magrib, kita } \\
\text { jam enam masih ... }\end{array}$ & $\begin{array}{l}\text { alih kode yang dilakukan guru ke } \\
\text { ragam tidak resmi dengan adanya } \\
\text { penyisipan kata tidak baku } \\
\text { "enggak" dalam tuturannya. } \\
\text { Kemudian susunan unsur kalimat } \\
\text { yang tidak sistematis juga } \\
\text { menyebabkan tuturan guru terlihat } \\
\text { tidak resmi. }\end{array}$ \\
\hline 2 & $\begin{array}{l}\text { Guru: masih terang kalau sore. Orang itu kan } \\
\text { jam enam sudah azan Magrib kan? Kalau kita } \\
\text { Magribnya jam enam lima puluh kan? Orang } \\
\text { itu sudah Magrib jam enam pas. Berarti } \\
\text { mungkin lima puluh menit pergeseran waktu } \\
\text { perputaran mataharinya antara Jakarta dengan } \\
\text { Aceh. Begitu juga dengan daerah-daerah yang } \\
\text { lain. Itulah yang namanya rotasi tadi. Nah, } \\
\text { kebiasaan makan. Ini uraian tadi, uraian } \\
\text { tentang kelelawar. Kelelawar itu biasa makan? }\end{array}$ & $\begin{array}{l}\text { Penggunaan alih kode ke ragam } \\
\text { tidak resmi yang ditunjukkan oleh } \\
\text { frasa (1) Orang itu kan, (2) } \\
\text { Magribnya, dan (3) jam enam pas. } \\
\text { Alih kode ke ragam tidak resmi } \\
\text { dimaksudkan guru agar peserta } \\
\text { didik tidak terlihat jenuh saat } \\
\text { pembelajaran berlangsung pada } \\
\text { jam terakhir kegiatan belajar. }\end{array}$ \\
\hline
\end{tabular}

\section{d. Alih Kode dari Ragam Tidak Resmi ke Ragam Resmi}

Penggunaan Alih kode dari ragam tidak resmi ke ragam resmi terlihat pada data berikut:

Tabel 4. Penggunaan Alih kode dari ragam tidak resmi ke ragam resmi

\begin{tabular}{|c|l|l|}
\hline No & \multicolumn{1}{|c|}{ Interaksi/komunikasi } & \multicolumn{1}{c|}{ Analisis } \\
\hline $\mathbf{1}$ & $\begin{array}{l}\text { Lebih detailnya, supaya kita tahu apa itu Venus. } \\
\\
\text { Lalu, kita uraikan, kita jelaskan bagaimana } \\
\text { bentuknya, bagaimana jenisnya, yang kita jawab } \\
\text { kemarin. Kemudian, di sini ada pertanyaan, apakah } \\
\text { pernyataan umumnya sudah jelas mengklasifikasi }\end{array}$ & $\begin{array}{l}\text { Alih kode ke ragam resmi } \\
\text { karena menggunakan semua } \\
\text { kata-kata baku dalam tuturan } \\
\text { guru }\end{array}$ \\
\hline $\mathbf{2}$ & $\begin{array}{l}\text { Nah, kita sudah bisa menjawab, kebetulan kemarin } \\
\text { kita sudah menjawabnya. Selanjutnya, tentang } \\
\text { kelelawar, masih di halaman 21. Kelelawar, } \\
\text { pernyataan umumnya apa? }\end{array}$ & $\begin{array}{l}\text { Menunjukkan alih kode ke } \\
\text { ragam resmi karena } \\
\text { mengunakan semua kata } \\
\text { baku dalam tuturan guru }\end{array}$ \\
\hline
\end{tabular}

Dari data yang ditemukan dapat dikatakan guru bahasa Indonesia di SMP

Negeri 3 Darul Hikmah hanya sedikit menggunakan alih kode ke dalam ragam

90 BRILIANT: Jurnal Riset dan Konseptual Volume 5 Nomor 1, Februari 2020 
resmi. Penggunaan ragam resmi dalam pembelajaran mendapat respons kaku dan kurang aktif dari peserta didik, bahkan di saat jam terakhir kegiatan pembelajaran peserta didik terlihat mudah bosan. Penggunaan ragam resmi juga membuat guru yang sudah terbiasa berbahasa daerah atau bertutur dalam ragam tidak resmi terlihat kaku dalam menyampaikan materi pembelajaran. Hal ini harus dihindari guru demi kelancaran proses pembelajaran.

\section{Bentuk Campur Kode}

\section{a. Campur Kode Berwujud Kata}

Saat peserta didik bertanya atau memberi pendapat dalam bahasa Aceh, baik sengaja atau tidak guru terkadang juga menjawab dalam bahasa Aceh. Campur kode BA berwujud kata terdapat pada data berikut:

Guru: Orange dengan sedikit kehitaman. Venus itu merupakan planet kedua dari matahari antara Merkurius dan ...

Data tersebut menunjukkan penggunaan campur kode berbentuk kata karena adanya penyisipan kata orange yang berasal dari bahasa Inggris. Selanjutnya:

Guru: Geulanteu. Nah, Meunyo kilat, kilat. Tapi Meunyoe petir, geulanteu.

Data di atas menunjukkan campur kode berbentuk kata karena adanya penyisipan kata (1) Geulanteu dan (2) Meunyo dari bahasa Aceh dalam tuturan.

Data selanjutnya terlihat pada tuturan guru berikut ini.

Guru: $N a$, mirip tikus. Ada taringnya?

Data tersebut menunjukkan penggunaan campur kode berbentuk kata karena adanya penyisipan kata " $N a$ " dari bahasa Aceh yang bermakna "ada".

Data selanjutnya juga menunjukkan penggunaan campur kode berbentuk kata seperti terdapat pada dialog berikut ini.

Guru: "Kumpulkan PR yang kemarin."

Siswa 1: "Buk, buku PR lôn tinggai, lôn kumpul singoh mantong jeut PR?" Guru: "Mengapa bisa tinggal?"

Siswa 1: "Lôn kujak sikula dari rumoh nek, Buk. Jeut buk oh"

Guru: "Jeut, tapi kamu harus kerjakan tugas lain ya."

Siswa 1: "Jeh, Ibuk"

Data di atas menunjukkan guru melakukan campur kode BA berbentuk kata 'jeut' yang bermakna 'boleh'. Campur kode BA tersebut dimaksudkan untuk menerima permintaan peserta didik mengumpulkan tugas besok. Karena peserta didik sudah melakukan kode BA berulang-ulang, guru pun akhirnya menjawab dengan kode BA. Akan tetapi, guru mencampur kembali kode BA tersebut dalam tuturan bahasa Indonesia.

\section{b. Campur Kode Berwujud Frasa}

Campur kode BA terkadang juga pernah dilakukan guru hanya sekedar untuk bercanda atau mencairkan suasana. Hal ini terlihat seperti pada data berikut

Guru: Geulanteu. Nah, Meunyo kilat, kilat. Tapi Meunyoe petir, geulanteu. Man yang ta eu geulanteu nyan pasti berwarna meublee, meublee meucahaya, puteh jih lagee kilat. Nah itu yang kita lihat, makanya di sini dikatakan Venus itu, dia itu berwarna orange dengan kilatan cahaya petir. Puteh agak-agak orange, cie ujo eu geulanteu. Man kadang meunyoe tanyoe ino 
di gampong biasa tapeugah, oe jak let sigoe geulanteu, koen tanyoe nyan, mustahil, itu cuma mitos, kata orang jaman dahulu, ya. Nah apa yang dimaksud dengan uraian ini?

Data di atas menunjukkan campur kode berbentuk frasa karena adanya penyisipan frasa dari bahasa Aceh dalam tuturan bahasa Indonesia. Frasa tersebut berupa (1) Meunyo kilat, (2) Meunyoe petir, geulanteu, (3 man yang ta eu geulanteu nyan pasti berwarna meublee, (4) meublee meucahaya, (5) puteh jih lagee kilat, (6) puteh agak-agak orange, (7) cie ujo eu geulanteu, (8) man kadang meunyoe tanyoe ino di gampong biasa tapeugah, (9) oe jak let sigoe geulanteu, (10) koen tanyoe nyan.

Selanjutnya komunikasi yang menunjukkan guru melakukan campur kode BA dalam bentuk frasa juga dapat dilihat pada data berikut:

Guru: "Reza, apa itu orientasi?

Siswa 1: "Perkenalan, Bu"

Guru: "Benar sekali, kenapa juga di tugas tidak Reza jawab? Bahkan hampir semua tugas yang ibu berikan Reza tidak jawab."

Siswa 1: "Baroe e hana meuphom, Buk"

Guru: "Hana meuphom. Reza, kenapa gak tanya?"

Interaksi tersebut menunjukkan guru melakukan campur kode BA berupa frasa "Hana meuphom. Reza, kenapa gak tanya?" "Tidak paham. Reza mengapa tidak bertanya?" Campur kode BA berupa frasa tersebut dimaksudkan guru untuk menegaskan kembali pernyataan peserta didik dengan cara mengulang pokok pernyataannya. Perilaku campur kode BA berupa frasa yang diulang oleh guru sebagai bentuk rasa sedikit kecewa terhadap tindakan peserta didik yang tidak bertanya pada pertemuan sebelumnya.

Guru yang ingin membuat peserta didik memahami kosakata bahasa Indonesia, terkadang juga menggunakan campur kode BA sebagai strategi. Hal tersebut dapat dilihat dalam interaksi berikut ini:

Guru: "Ilham, coba ceritakan produk apa yang sudah bisa kamu buat melalui sebuah teks prosedur."

Ilham: "Waktu pelajaran prakarya, kami diminta ibu buat keterampilan, dari limbah sampah. Saya diajarkan kakak saya memuat gantungan kunci dari Bruk u Buk." (Semua peserta didik tertawa)

Guru: (tersenyum) "Bruk $u$ bahasa Indonesianya batok kelapa"

Campur kode BA pada data di atas berupa 'bruek $u$ ' artinya 'batok kelapa' dimaksudkan guru untuk menambah perbendaharaan kosakata bahasa Indonesia yang dimiliki oleh peserta didik. Guru memberi penekanan makna 'batok kelapa' dengan mengulang kembali penggunaan frasa 'bruek $u$ ' seperti yang diucapkan oleh peserta didik.

Kondisi lain yang menunjukkan adanya campur kode dalam bentuk frasa terjadi ketika Guru mencampur beberapa frasa dalam sebuah tuturan seperti data berikut ini:

Guru: "Kalau kalian itu tidak benar-benar belajar, itulah yang membuat kita itu jadi salah pilih, dan jangan juga, meu bahasa, oh loen biasa caroeng that, nyoe pasti loen jeut, pasti loen jeut. Jadi uroe nyoe pileh, yang nyoe baroe loen salah. Percayakanlah kata hati kecilmu. Setelah kita memilih kalau itu kita anggap memang benar, yakinkan pada hati sendiri, 
yakinkan akan ingatan, ibu harap kalian di sana itu bayangkan seakan-akan ibu yang ada di depan sedang menjelaskan. Kalau itu yang kalian lakukan, itu pasti benar. Jadi setiap Bapak memberikan simulasi, jangan bilang, han ek le Bu, ka hek, kaseb Bu, ka teubit maen-maen. Ka abeh tahu Bu, ka abeh tempe, ka abeh bakwan. Jangan itu, apa yang ibu kasih itu yang kalian belajar, kemaren baru beberapa yang ibu kasih sudah keluar di simulasi. Simulasi besok tidak jauh juga larinya. Lari ke samping satu langkah, mundur ke belakang dua. Kalian, kamu bukan nggak bisa, tapi penyakit beuo, ya. Jangan ada lagi.

Dari data di atas terlihat campur kode berupa penyisipan unsur bahasa Aceh berbentuk frasa (1) meu bahasa (2) han ek le Bu (3) ka hek, (4) kaseb Bu, (5) ka teubit maen-maen. (6) Ka abeh tahu Bu,(7) ka abeh tempe,(8) ka abeh bakwan. Penyisipan unsur bahasa Aceh berbentuk frasa tersebut dimaksudkan guru untuk memberitahukan kembali alasan-alasan yang biasa disampaikan oleh peserta didik bahwa itu tidak penting untuk diungkapkan dan hanya akan membuat mereka semakin malas.

\section{c. Campur Kode Berwujud Baster}

Campur kode berupa baster atau campur kode campuran (hybrid codemixing) yang ada pada tuturan guru dalam pembelajaran bahasa Indonesia di SMP Negeri 3 Darul Hikmah dapat dilihat pada data berikut:

Guru: Geulanteu. Nah, Meunyo kilat, kilat. Tapi Meunyoe petir, geulanteu. Man yang ta eu geulanteu nyan pasti berwarna meublee, meublee meucahaya, puteh jih lagee kilat. Nah itu yang kita lihat, makanya di sini dikatakan Venus itu, dia itu berwarna orange dengan kilatan cahaya petir. Puteh agak-agak orange, cie ujo eu geulanteu. Man kadang meunyoe tanyoe ino di gampong biasa tapeugah, oe jak let sigoe geulanteu, koen tanyoe nyan, mustahil, itu cuma mitos, kata orang jaman dahulu, ya. Nah apa yang dimaksud dengan uraian ini?

Campur kode pada data di atas berbentuk baster atau campuran karena guru menyisipkan bahasa Aceh dan menyisipkan bahasa Indonesia secara berselang-seling. Bahkan guru juga mencampur tuturan dengan bahasa Inggris. Hal ini terlihat jelas pada kata (1) Meunyo kilat, (2) Meunyoe petir, (3) berwarna meublee, (4) meublee meucahaya, (5) lagee kilat, (6) berwarna orange, (7) Puteh agak-agak orange, (8) Man kadang, dan (9) biasa tapeugah. Hal ini biasa dilakukan oleh guru saat mendeskripsikan suatu keadaan yang belum bisa dipahami oleh peserta didik atau pun peserta didik memahami keadaan tersebut, tetapi tidak bisa mendeskripsikannya ke dalam bahasa Indonesia.

\section{c. Campur Kode Berwujud Klausa}

Campur kode berwujud klausa yang digunakan dalam tuturan guru saat pembelajaran dapat dilihat pada data berikut:

Guru: Nah, ini bersifat umum, inoe jipeugah, miseu jih geutanyoe peugah lhong, yang tanyoe kaloen uroe nyan saboh koen? Tetapi, dia itu banyak jenisnya. Kadang ketika kita pergi ke suatu tempat kita lihat kalon tersebut ataupun kelelawar, di sini misalnya telinganya bulat, kita pergi ke daerah orang, dapatlah kita lihat di sana nanti telinganya panjang dan berbulu-bulu, ada taringnya yang panjang. Awak kah na toem drop simantoeng? 
Data di atas membuktikan adanya pencampuran kode bahasa Aceh berupa klausa dalam sebuah tuturan guru. Klausa tersebut berupa (1) inoe jipeugah, (2) miseu jih geutanyoe peugah lhong, (3) yang tanyoe kaloen uroe nyan saboh koen, (4) Awak kah na toem drop simantoeng?

\section{PEMBAHASAN}

Hasil penelitian mengenai alih kode dan campur kode dalam proses pembelajaran bahasa Indonesia di SMP Negeri 3 Darul Hikmah menunjukkan bahwa guru mata pelajaran bahasa Indonesia menggunakan lebih dari satu bahasa saat proses pembelajaran berlangsung. Bahasa Indonesia digunakan sebagai pengantar resmi sedangkan bahasa Aceh digunakan untuk menyesuaikan diri dengan situasi dan kondisi yang memungkinkan digunakannya bahasa tersebut. Selain kedua bahasa tersebut, bahasa Arab juga digunakan dalam mengawali pembelajaran sebagai ucapan doa, ucapan syukur, atau sebagai ungkapan keterkejutan. Sementara bahasa Inggris hanya muncul pada sebagian kecil tuturan guru dalam pembelajaran bahasa Indonesia.

Mengenai alih kode dan campur kode dalam proses pembelajaran bahasa Indonesia di kelas VII, kelas VIII, dan kelas IX SMP Negeri 3 Darul Hikmah Kabupaten Aceh Jaya, guru dan peserta didik masih menggunakan dua bahasa (Aceh dan Indonesia) komunikasi dalam situasi resmi. Dalam situasi non resmi, guru dan peserta didik lebih memilih menggunakan bahasa daerah (bahasa Aceh).

Kegiatan pembelajaran bahasa Indonesia di kelas VII, kelas VIII, dan kelas IX SMP Negeri 3 Darul Hikmah Kabupaten Aceh Jaya, guru dan peserta didik menggunakan bahasa Indonesia sebagai alat tutur dan sering kali beralih dan bercampur ke dalam bahasa Aceh ataupun sebaliknya. Hal itu disebabkan adanya status sosial yang berbeda-beda atau faktor kebiasaan dalam menggunakan bahasa Aceh. Oleh sebab itu, saat proses pembelajaran berlangsung guru menggunakan bahasa Indonesia dan bahasa Aceh sehingga terjadi alih kode dan campur kode.

Chaer \& Agustina (2010: 109) yang menyatakan bahwa lawan bicara atau lawan tutur dapat menyebabkan terjadinya alih kode misalnya karena si penutur ingin mengimbangi kemampuan berbahasa si lawan tutur itu, tidak terlihat pada analisis data dalam penelitian ini. Akan tetapi, dari hasil penelitian membuktikan secara garis besar penggunaan alih kode dan campur kode dalam pembelajaran bahasa Indonesia di SMP Negeri 3 Darul Hikmah bertujuan untuk memperlancar komunikasi antara penutur (guru) dan lawan tutur (peserta didik). Guru ingin memudahkan peserta didik dalam memahami tuturan guru atau dalam menjawab pertanyaan baik dijawab secara serempak maupun individu. Meskipun demikian, dalam penelitian ini ditemukan juga beberapa peserta didik yang paham maksud guru tapi hanya mengikuti jawaban peserta didik yang dominan saat merespons tuturan guru. Sebagian peserta didik yang kurang aktif dalam pembelajaran bahasa Indonesia, alih kode dan campur kode dilakukan oleh guru untuk mendorong keaktifan peserta didik dalam proses pembelajaran.

Alih kode dan campur kode juga dimaksudkan guru untuk memotivasi peserta didik kalau mereka tidak belajar dengan sungguh-sungguh, tidak boleh menganggap remeh pelajaran bahasa Indonesia sehingga membuat mereka bisa keliru dalam memilih jawaban. Peserta didik dituntun untuk mempelajari materi yang sudah diberikan guru dan memilih jawaban sesuai hati nurani untuk memperbaiki jawaban yang pernah dijawab salah. Kemudian peserta didik 
diminta untuk tidak memberikan banyak alasan agar bisa keluar saat guru sedang menjelaskan materi pelajaran. Selain itu, guru bermaksud memecahkan permasalahan yang dialami peserta didik dengan cara meyakinkan peserta didik bahwa apa yang mereka pelajari, itulah yang akan keluar di soal Ujian Nasional Berbasis Komputer (UNBK). Dengan melakukan campur kode guru berusaha memberi solusi bahwa soal bahasa Indonesia saat UNBK akan sama dengan soal simulasi UNBK. Dapat disimpulkan, campur kode dari BI ke BA atau dari BA ke BI dilakukan guru sebagai salah satu alternatif strategi penyelesaian masalah dalam pembelajaran.

\section{a. Alih Kode dalam Pembelajaran Bahasa Indonesia}

Dalam pembelajaran bahasa Indonesia di sekolah yang mayoritas guru dan peserta didiknya bersuku Aceh, secara alamiah sudah tentu alih kode bisa terjadi di sela-sela percakapan dalam pembelajaran. Hanya saja, terkadang guru tidak begitu menonjolkan penggunaan bahasa Aceh karena sadar harus berbicara dalam bahasa Indonesia. Agar peserta didik terampil dalam berbahasa Indonesia, guru menggunakan berbagai strategi. Salah satunya, dengan cara guru melakukan alih kode BA sebagai pendekatan, ajakan, atau penegasan ulang dalam penguasaan materi yang sedang dipelajari peserta didik.

Ketika pembelajaran berlangsung, guru menggunakan bahasa Indonesia sebagai bahasa utama dalam menjelaskan materi pelajaran. Kemudian, saat peserta didik sedang mengerjakan tugas dalam kegiatan pembelajaran, peserta didik sering mengajukan pertanyaan dalam bahasa Aceh, bahkan ada peserta didik yang mengungkapkan pendapat dalam bahasa Aceh. Guru menggunakan alih kode ke dalam bahasa Aceh saat peserta didik terlihat kurang paham ketika guru menjelaskan materi dalam bahasa Indonesia. Peserta didik terlihat menunjukkan pemahamannya setelah dijelaskan guru dalam bahasa Aceh. Pada waktu tertentu, guru juga menggunakan bahasa Aceh untuk menegur atau menasihati peserta didik yang tidak aktif mengikuti kegiatan pembelajaran. Alih kode bahasa Aceh juga digunakan guru sebagai bentuk pendekatan emosional dalam berkomunikasi dengan peserta didik karena mayoritas peserta didik berbahasa Aceh dalam kehidupan sehari-hari.

Alih kode ke dalam Bahasa Aceh atau ke dalam bahasa Indonesia terkadang juga menjadi solusi dalam pembelajaran ketika peserta didik tidak memberikan informasi atau pendapat yang diharapkan oleh guru. Dengan adanya penggunaan alih kode ke dalam bahasa Aceh, peserta didik mengungkapkan banyak informasi yang tidak bisa diungkapkannya dalam bahasa Indonesia.

Alih kode ke dalam bahasa Indonesia sendiri sudah menjadi kewajiban guru bahasa Indonesia ketika topik pembahasan dalam pembelajaran sudah menggunakan bahasa lain. Hal ini dimaksudkan guru agar peserta didik menyadari bahwa mereka berada pada konteks pembelajaran bahasa Indonesia yang menuntut mereka harus terampil menulis dan berbicara dalam bahasa Indonesia.

\section{b. Campur Kode dalam Pembelajaran Bahasa Indonesia}

Dalam kegiatan pembelajaran guru bahasa Indonesia di SMP Negeri 1 Darul Hikmah bisa dikatakan sering menggunakan campur kode dalam kegiatan pembelajaran. Hal ini dimaksudkan selain untuk memberikan pemahaman baru atas sebuah kata juga untuk menambah kumpulan kosakata bahasa Indonesia bagi peserta didik. 
Campur kode juga tidak terlepas dari kebiasaan penggunaan bahasa Aceh dalam kehidupan sehari-hari. Sehingga tanpa sengaja, terkadang guru juga menyisipkan kata, frasa, atau klausa dari bahasa Aceh saat berkomunikasi dengan bahasa Indonesia. Begitu juga sebaliknya, guru sering menyisipkan kata, frasa, atau klausa dari bahasa Indonesia saat berkomunikasi dalam bahasa Aceh.

\section{KESIMPULAN}

Berdasarkan hasil analisis alih kode dan campur kode dalam pembelajaran bahasa Indonesia di SMP Negeri 3 Darul Hikmah Kabupaten Aceh Jaya dapat disimpulkan bahwa bentuk alih kode dalam pembelajaran Bahasa Indonesia di SMP Negeri 3 Darul Hikmah berupa alih bahasa dan alih ragam. Alih bahasa berupa alih kode dari Bahasa Indonesia ke Bahasa Aceh, alih kode terjadi dari Bahasa Aceh ke Bahasa Indonesia, sedangkan alih ragam dari ragam formal ke ragam tidak formal dan sebaliknya. Adapun campur kode yang terjadi berupa penyisipan kata, penyisipan frasa, baster (hybrid), dan penyisipan klausa.

Alih kode ke dalam bahasa Aceh dimaksudkan guru sebagai bentuk pendekatan emosional dan sebagai strategi untuk mendapatkan informasi yang maksimal dari peserta didik. Sedangkan Alih kode ke dalam bahasa Indonesia dilakukan guru untuk mengajak peserta didik mendeskripsikan pengetahuan yang dimiliki ke dalam bahasa Indonesia yang baik. Alih kode ke dalam ragam tidak resmi dimaksudkan guru untuk membuat suasana pembelajaran lebih santai atau tidak terlalu kaku, terutama pada jam pelajaran terakhir. Sedangkan Alih kode ke dalam ragam resmi dimaksudkan guru untuk membuat peserta didik mampu mengungkapkan pengetahuan atau simpulan akhir mereka dengan bahasa Indonesia yang benar. Campur kode dimaksudkan guru untuk memberikan pemahaman baru terhadap sebuah kata dan untuk menambah kumpulan kosakata peserta didik baik dalam bahasa Aceh maupun dalam bahasa Indonesia.

\section{SARAN}

Berdasarkan kesimpulan tersebut maka penulis menyarankan agar Guru dapat menyesuaikan bentuk penggunaan alih kode dan campur kode untuk meningkatkan penguasaan bahasa Indonesia peserta didik agar baik dan benar. Dalam proses pembelajaran Guru dapat memilih bentuk alih kode dan campur kode yang relevan dengan materi yang pelajaran yang sedang disampaikan. Artinya guru juga perlu menambah kosakata baru di bidang bahasa bagi peserta didik dengan adanya penggunaan alih kode dan campur kode

\section{DAFTAR RUJUKAN}

Arikunto, S. 2006. Manajemen Penelitian. Jakarta: Asdi Mahasatya.

Chaer, Abdul dan Leonie Agustina. 2010. Sosiolinguistik perkenalan Awal. Jakarta: Rineka Cipta.

Hanafiah, M. Adnan dan Ibrahim Makam. 1984. Struktur Bahasa Aceh. Jakarta: Pusat Pembinaan dan Pengembangan Bahasa Departemen Pendidikan dan Kebudayaan

Indrayani, Nanik. 2017. "Penggunaan Campur Kode dan Alih Kode dalam Proses Pembelajaran di SMPN Ubung Pulau Buru”. Totobuang 5(2): 299-314.

Mahsun, M.S. 2007. Metode Penelitian Bahasa. Jakarta: PT Raja Grafindo Persada. 
Nababan, P.W.J. 1991. Sosiolinguistik Suatu Pengantar. Jakarta: PT Gramedia Pustaka Utama.

Nazir, Moh. 2003. Metode Penelitian. Jakarta: Ghalia Indonesia.

Ohoiwutun, Paul. 2007. Sosiolinguistik Memahami bahasa dalam Konteks Masyarakat dan Kebudayaan. Jakarta: Kesaint Blanc.

Rahardi, Kunjana R. 2001. Sosiolinguistik, Kode dan Alih Kode. Cilebon Timur: Pustaka Pelajar.

Rulyandi, dkk. 2014. "Alih Kode dan Campur Kode dalam Pembelajaran Bahasa Indonesia di SMA". Jurnal Paedagogia, 17(1)

Sugono, Dendy. 2002. Berbahasa Indonesia dengan Benar. Jakarta: Puspa Swara.

Sumarsono dan Paina Partana. 2002. Sosiolinguistik. Yogyakarta: Sabda

Susmita, Nelvia. 2015. "Alih Kode dan Campur Kode dalam Pembelajaran Bahasa Indonesia di SMP Negeri 12 Kerinci". Jurnal Penelitian Universitas Jambi Seri Humaniora, 17(2): 87-98.

Suwito. 1983. Sosiolinguistik. Surakarta: Henary Offset Solo.

Undang-Undang Republik Indonesia Nomor 24 tahun 2009 Pasal 27

Widarsini, Ni Putu N \& Suida, I Made. 2016. "Bahasa-Bahasa di Aceh: Sajian awal profil sosiolinguistik". Prosiding Seminar Nasional Bahasa Ibu. Denpasar: Udayana University Press 